\title{
Young Romanians: Entrepreneurs in their Home Country?
}

\author{
Mihai VOLINTIRU \\ The Bucharest University of Economic Studies, Romania \\ mihai.volintiru@gmail.com \\ Clara VOLINTIRU \\ The Bucharest University of Economic Studies, Romania \\ clara.volintiru@rei.ase.ro \\ George STEFAN \\ The Bucharest University of Economic Studies, Romania \\ stefan.george.m@gmail.com
}

\begin{abstract}
As outward migration and brain drain reach record numbers in Romania, we explore the pull factors that might contribute to a reversal. This paper presents the findings of the first large scale survey on the entrepreneurial intentions of the Romanian Diaspora. We have specifically targeted the category of graduates and young professionals as having the highest flexibility to relocate. The findings of our survey show a large inclination to start a business venture in the home country (79\%). The main field in which the young Romanian Diaspora would be interested to develop an entrepreneurial project is IT\&C (35.67\%). We compare those findings with those from a domestic survey targeting the same age group, and find little differences in preferences, suggesting that country of residence is not a significant differentiating factor in the decision to start a business. The main perceived impediment for entrepreneurship in Romania is still excessive bureaucracy (76.03\%). The reverse migration patterns are important for any developing economy in the world, as the case of Romania shows, where the return of the 200,000 Romanians (5\%) could (gradually) contribute on the medium term with more than 11.5 billion euro to the country's GDP.
\end{abstract}

Keywords: entrepreneurship; Romania; Diaspora; outward migration; EU funding;

JEL Codes: O15; M20; D84;

DOI: http://doi.org/10.24818/ejis.2018.06

\section{Introduction}

For the past years, the outward migration phenomenon has become increasingly worrisome for Romania. A number of studies from the United Nations (2018) or Eurostat (2018) have highlighted how the outward migration patterns in Romania have increased gradually. According to Eurostat (2018), 1 in 5 Romanians of working age reside in another member state. Not only does Romania have the highest rate of outward migration of working age population in the European Union at the moment, but it also records the highest growth over the past decade, moving from $7.4 \%$ in 2007 to $19.7 \%$ in 2017 . Zaharia et al. (2016) clearly showed that the Romanian labour market is neither attractive for Romanians, or immigrants due to the relatively low level of wages it can supply.

Certain counties in Romania record some of the highest rates of migration in the EU NUTS 3 regions. Amongst the affected counties, there are: Hunedoara, Gorj, Mehedinți, Olt, Teleorman, Botoșani, Brăila and Tulcea. These counties in Romania are supplying the bulk of the in-ward migration in the European Union. While countries like Germany have recently received a great number of asylum seekers from the Middle East (especially 
conflict-ridden Syria), they have however also received an important number of migrants from Central, Eastern and Southern Europe, amongst which the first ranked country of emigration is Romania (O’Sullivan, 2017).

Based a recent study from the World Bank, there is a simultaneous phenomenon that is to be considered in Romania: internal migration to major cities (Cristea et al., 2017). According to the report, principal and secondary cities account for in-between 10\%-30\% of the total population in each EU country and generate in-between $50 \%-70 \%$ of the national GDP (Zaharia et al., 2016). As such, beyond the capital city of Bucharest, an important economic growth dynamic could be recorded in other important municipalities, thus making them more attractive for Romanians than other cities in Europe. The more attractive the opportunities for work and life become in Romanian cities, the more likely it is that internal migration rather than external migration will occur.

The Romanian Diaspora, around 4 million persons, annually contribute to the economy through remittances - compensation of employees and personal transfers - with more than 3.1 billion of euro, approximately $2 \%$ of GDP (latest data estimated by World Bank Migration and Remittances Data in 2016 and 2017). As such, the Romanian Diaspora is an important source of capital transfers. It is therefore interesting to assess to what extent this capital can be used for investments in entrepreneurial start-ups, as opposed to the general consumption.

Given the high levels of outward migration and brain drain in Romania, we find it timely to explore the pull factors that might contribute to a reversal. We take pull factors in this case to be those incentives to come back home that are derived from the current Romanian context (e.g. incentive to start a business back home), rather than factors that are innate to the subject (i.e. personal preferences), or to the context in the destination country (e.g. antiimmigration policies). We focus specifically on: (1) entrepreneurial intentions in general, and (2) the desire to start a business in Romania, as an example of a pull factor that might contribute to a reverse migration.

This paper presents the findings of the first large scale survey on the entrepreneurial intentions of the Romanian Diaspora. We have specifically targeted the category of graduates and young professionals as having the highest flexibility to relocate. Previous studies (Gribble, 2008) have shown that it is the policies that target young graduates that can have the highest impact in facilitating a reversed migration pattern.

If we account for these coupled dynamics, we need only think naturally about the extent to which Romanians living abroad might be willing to firstly come back home, and secondly under what circumstances. To this purpose we took the case study of an EU funded project implemented by the Romanian Government offering financial support for Romanians looking to start a business. Diaspora Start Up programme is funded from the Romanian Operational Programme Human Capital 2014-2020 and is designed to increase nonagricultural employment in other cities than Bucharest. The respondents of our survey were persons that would be eligible to apply to this programme, and we subsequently conducted in-depth interviews with a series of applicants to this programme. With an allocation of approximately 30 million EUR, this programme aims to create opportunities for citizens residing abroad to return to Romania by opening a business back home. A similar, yet much larger programme Start-up Nation has been targeting only the Romanians living in their home country, with a budget of approximately 700 mil EUR. These different programmes allow us to have a relatively comparable set of institutional incentives for both the Diaspora and Romanians living at home. In other respects, we consider market-based incentives (e.g. 
economic growth, cyclical phase, macro-economic conditions, competition) to be ceteris paribus for young Romanians that want to start a business in their home country.

There are different strings of the literature that have addressed the issues we are presenting in this article. Firstly, our assessment on Romania resonates with a series of articles concerned with the outward migration phenomenon across the globe, as a subcategory of developmental studies. Through the process of global integration, a growing number of persons are leaving their home countries to live, study or work abroad (Held and McGrew, 2007; Castells, 2011; Castles et al., 2013, Giddens, 2013). It is important to note in this context that the identity and personal traits and choices of a migrant person have become increasingly blurred categories, as people are beginning to develop an ever-increasing mobility that no longer assumes relocation as a one-off situation in a person's life, as it was the case decades ago (Kalra et al., 2005; Hirst et al., 2015; Giddens, 2018; Papastergiadis, 2018).

From the general process of migration, the present article is attached to a specific aspect of the community of people from a given country that live, study and/or work abroad: the diaspora. A couple of decades ago, Gerard Chaliand and Jean-Pierre Rageau define the diaspora as "the collective forced dispersion of religious and/or ethnic group [their emphasis], precipitated by a disaster, often of a political nature" (1995: xiv).

In this context professor Robin Cohen talks about the underlying implications for the diasporas in coining the term "global diasporas" (i.e. global mobility of the various categories of diaspora such as victim, labour, trade, imperial, and cultural diaspora) (2008), while Nicholas Van Hear refers to "new diasporas" (i.e. post-Cold War migration that takes a new dimension and new character form due to technological and social changes) (2005). In effect, the growth of complex transnational identities has created the basis for interdisciplinary scholarly programmes that find themselves at the intersection of migration studies and those looking at such issues as nationalism, identities, and international relations.

A connected phenomenon to the outward migration, and formation of diasporas, developing countries are now increasingly facing the issue of the "brain drain" or the loss of skilled personnel due to labour market mobility at regional and global level. Much like the flow of capital to markets that offer the most propitious settings, so too has labour (a much less mobile production factor) started to slowly react to market conditions. Michel Beine and his colleagues emphasise the need to distinguish between different phases of brain drain, as the first phase is potentially beneficial, when accounting for "the fact that migration opportunities foster investments in education since it is awarded a higher expected return when the economy is opened to migrations", and they call this the "brain effect" (Beine et al., 2001, p.287). Still, they also admit the detrimental effect produced in the second stage by "the departure of some, if not all educated agents", which they call the "drain effect" (Beine et al., 2001).

On the back of this vast literature on diasporas, we aim in this article to address a niche aspect of the circumstances under which people from the diaspora would consider moving back home. We take the specific case of Romania and focus on the appeal of entrepreneurial activity. The literature shows that the diaspora could have a powerful positive economic contribution through entrepreneurial activities (Newland and Tanaka, 2010, Riddle et al., 2010). With whatever motivation to come back, be it economically driven, or socially driven, Van Hear asks an important question: "Is diaspora now the inevitable concomitant of migration?" and he shows that this is not necessarily the case, for "if diaspora formation has accelerated in recent times, so too has the unmaking of diasporas, (...) these 
regroupings may involve voluntary or involuntary movements of people back to their place of origin - however notional or putative this place of origin may be" $(2005$, p.6).

In the following sections, we firstly explore in this article potential correlations of various personal traits (e.g. education, ideas, risk-aversion, self-determination) with entrepreneurial behaviour, across EU member states to see which hold for Romanians. Subsequently, based on an original assessment, we compare and contrast perceptions of young Romanians living in the diaspora and at home towards starting an entrepreneurial project in their home country, and we find little differences. Based on the survey data, we also find that there is a much higher prevalence of personal traits and the stage in which a person finds herself (e.g. recently graduated, finished a fixed term employment contract), than a consideration of contextual conditions. We could ascribe thus a much more intensive intrinsic incentive of relocation back home than an exogenous one based on pull factors of attraction. In this part of our assessment, we make use of an original questionnaire that we apply to young Romanians living in the Diaspora and at home, as well as a series of in-depth interviews with people from the Romanian Diaspora that are looking to start a business back home. Finally, we propose a set of scenarios for potential reverse migration patterns accounting for a relatively strong preference for returning home to start a business venture amongst young Romanians. While the extension of the survey results to the entire Romanian population living abroad is not possible, as we only focus here on young people, it is useful to conceptualise the economic impact of alternative dimensions of migration towards the home country.

\section{Perception of Entrepreneurial Capabilities in Romania Compared to Other EU Countries}

In this section, we highlighted some characteristics that individuals in Romania believe they have or have acquired through the educational process. Also, we emphasized the position of Romania relative to the other EU Member States. The data source is the Eurobarometer on Entrepreneurship realised by European Commission in 2015.

We use answers from the Eurobarometer on Entrepreneurship related to perception / selfperception of individuals regarding the role of educational environment, risk and the ability to generate ideas. We selected only the sum of the "Agree" and "Strongly Agree" at questions from the table below provided by those surveyed. Then, some answers of those questioned were correlated with the number of private sector companies per 1000 inhabitants in the EU Member States.

Table 1 shows the answers of Romanian respondents at European Commission Eurobarometer. We bundled the self-perception of Romanian respondents regarding their entrepreneurial characteristics in four main groups: (i) Education; (ii) Ideas; (iii) Risk; (iv) Self-determination. Also, the comparison with EU average helped us to consider that, in terms of self-perception and capability, it seems that Romanian youngsters are above EU27 average when we look at the support of education for entrepreneurial capabilities (i.e. to understand the entrepreneurs and their role in society). At the same time, there is a selfperception in terms of new ideas and taste for taking risks above the EU27 average. Below, but close the EU27 average, is the percentage of people who consider that, in general, life is determined mainly by the chance and not by the own actions. 
Table 1. Perceptions of Entrepreneurial Capabilities

\begin{tabular}{|c|c|c|c|c|c|}
\hline Group & Questions & Metric & Ro & EU27 & $\begin{array}{c}\text { Diff. vs. } \\
\text { EU } 27\end{array}$ \\
\hline \multirow{3}{*}{ Education } & $\begin{array}{l}\text { My school education made me } \\
\text { interested to become an entrepreneur } \\
\text { - Do you agree with? }\end{array}$ & \multirow{7}{*}{$\begin{array}{l}\text { Sum of } \\
\text { answers with } \\
\text { Agree \& } \\
\text { Strongly } \\
\text { Agree }\end{array}$} & $41.4 \%$ & $24.4 \%$ & $\begin{array}{c}\text { Above } \\
\text { average }\end{array}$ \\
\hline & $\begin{array}{l}\text { My school education helped me to } \\
\text { better understand the role of } \\
\text { entrepreneurs in society - Do you } \\
\text { agree with? }\end{array}$ & & $56.1 \%$ & $44.4 \%$ & $\begin{array}{c}\text { Above } \\
\text { average }\end{array}$ \\
\hline & $\begin{array}{l}\text { My school education gave me skills } \\
\text { and know how that enable me to run a } \\
\text { business - Do you agree with? }\end{array}$ & & $44.2 \%$ & $39 \%$ & $\begin{array}{c}\text { Above } \\
\text { average }\end{array}$ \\
\hline Ideas & $\begin{array}{l}\text { I am an inventive person who has } \\
\text { ideas - To what extent do you agree } \\
\text { with the following statements? }\end{array}$ & & $84.4 \%$ & $80.8 \%$ & $\begin{array}{c}\text { Above } \\
\text { average }\end{array}$ \\
\hline Risk & $\begin{array}{l}\text { In general, I am willing to take risks - } \\
\text { To what extent do you agree with the } \\
\text { following statements? }\end{array}$ & & $72.9 \%$ & $64.9 \%$ & $\begin{array}{c}\text { Above } \\
\text { average }\end{array}$ \\
\hline \multirow{2}{*}{$\begin{array}{c}\text { Self- } \\
\text { determination }\end{array}$} & $\begin{array}{l}\text { My life is determined by my own } \\
\text { actions, not by others or by chance - } \\
\text { To what extent do you agree with this } \\
\text { statement? }\end{array}$ & & $81.8 \%$ & $84 \%$ & $\begin{array}{c}\text { Below } \\
\text { average }\end{array}$ \\
\hline & $\begin{array}{l}\text { If I see something I do not like, I } \\
\text { change it - To what extent do you } \\
\text { agree with the following statements? }\end{array}$ & & $83.8 \%$ & $84 \%$ & $\begin{array}{c}\text { Below } \\
\text { average }\end{array}$ \\
\hline
\end{tabular}

Source: Eurobarometer on Entrepreneurship, European Commission (2015)

However, there is some evidence that, even the Romanian youngster have a good selfperception regarding entrepreneurial abilities, the factual results are very low. Figures below presents the relationship between the number of private sector companies from Romania at 1000 persons at the end of 2016 and the perception of creativity (Figure 1) on the one hand, and the perception of the support of educational system to entrepreneurial understanding (Figure 2), on the other hand. We analyse the Eurobarometer Survey data for all 27 EU Member States.

Thus, in Romania, the rate of private sector companies at 1000 persons is one of the lowest in EU, close to Germania and UK, countries with a larger population than Romania -, despite the good score at both creativity self-perception and educational system support. So, our finding is that we see in Romania a very positive perception of individuals entrepreneurial capabilities - one of the best in EU, but there is no capacity to translate these characteristics into strong, sustainable businesses. 
Figure 1. The Correlation between the Number of Private Sector Companies and Creativity Self-perception

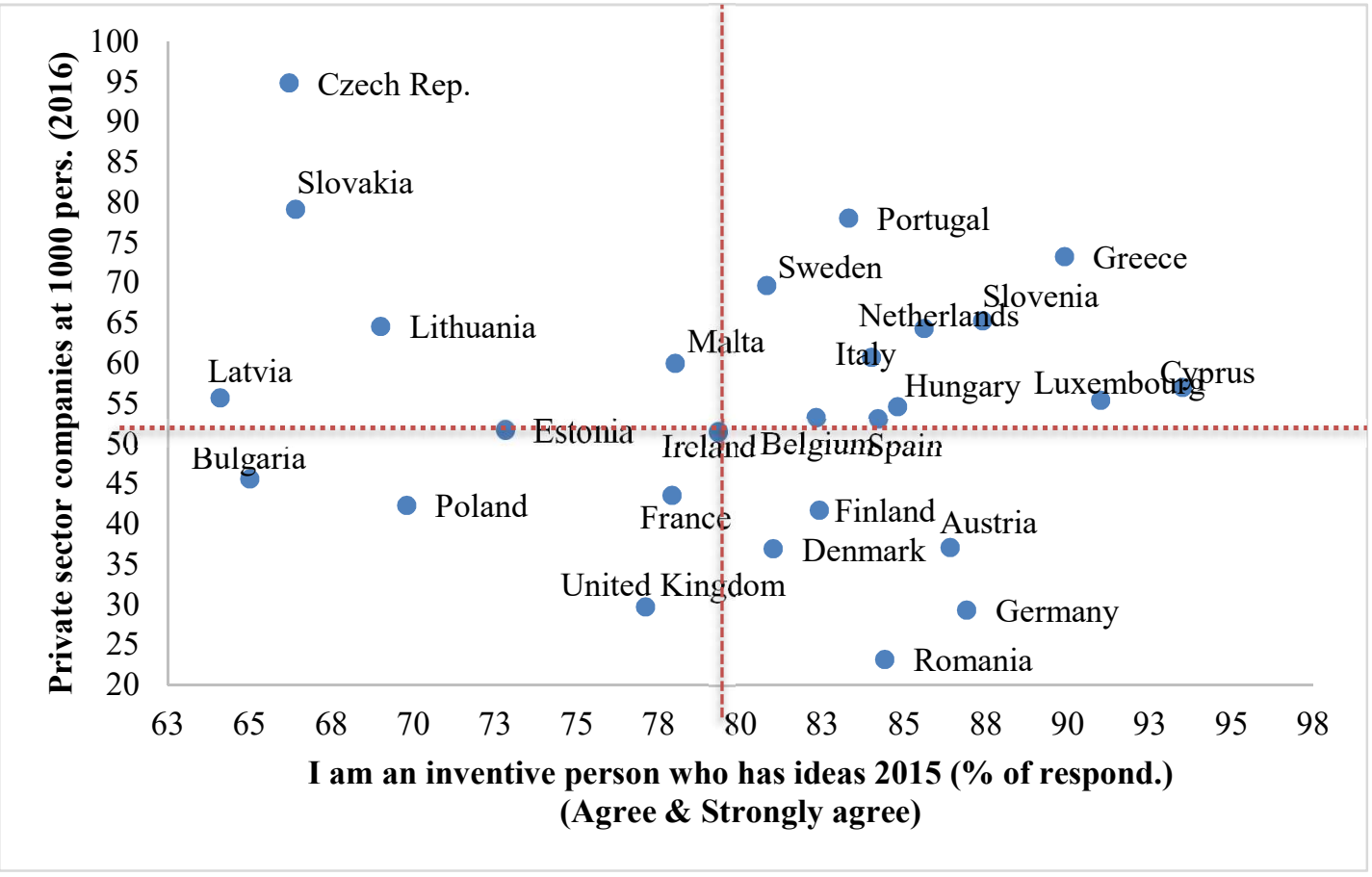

Source: Eurobarometer on Entrepreneurship, European Commission (2015), Eurostat and Romanian National Institute of Statistics

Figure 2. The Correlation Between the Number of Private Sector Companies and Education?

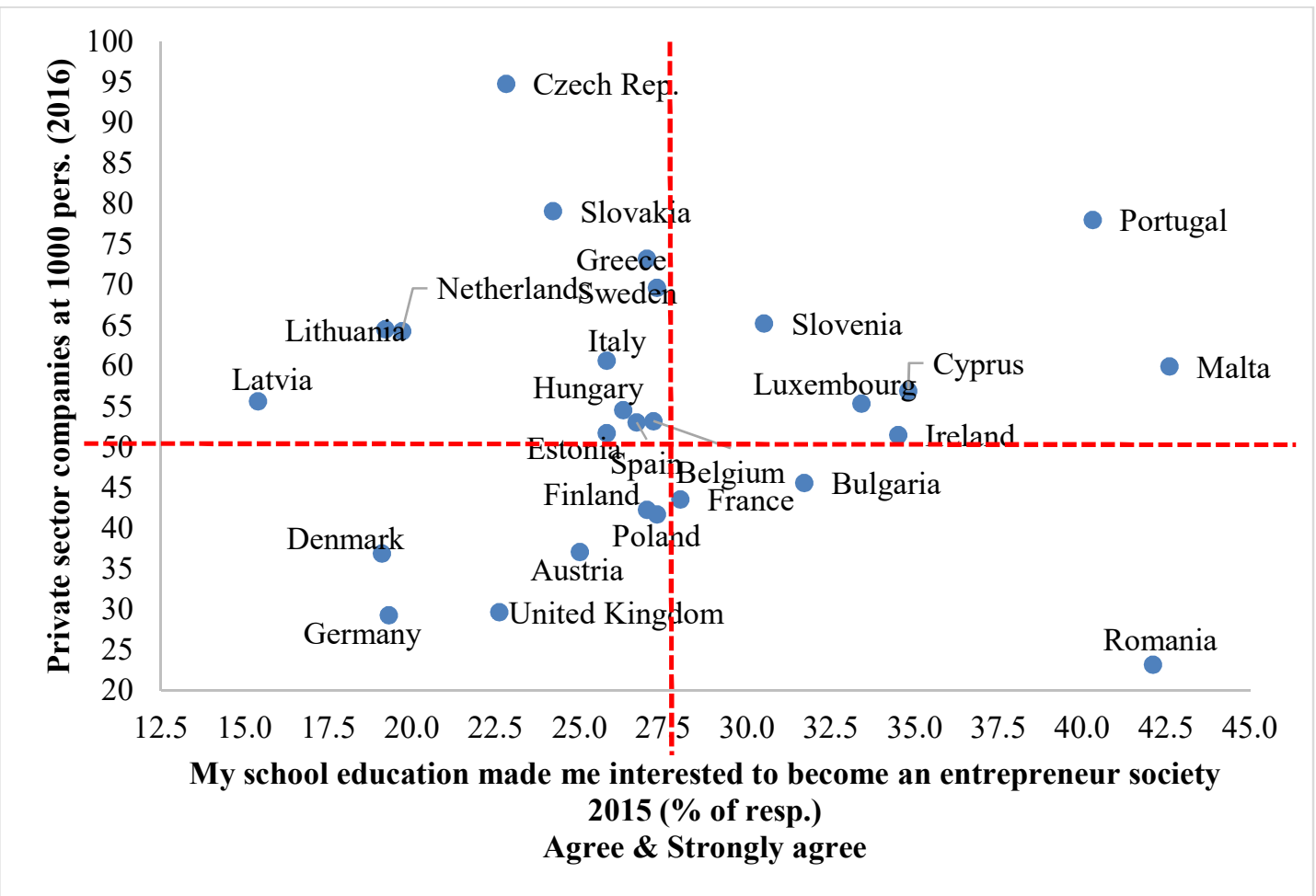

Source: Eurobarometer on Entrepreneurship, European Commission (2015), Eurostat and Romanian National Institute of Statistics 
One of the explanations could be the institutional barriers to create and develop companies as we see in the previous section. Another explanation could be the heavy access to finance (i.e. through loans, stock market, debt market) for the SMEs, which impede the business plans in first years of activity. One instrument to support investment could be state aid schemes, that in the last ten years were an important source of funds for some sector with good results in Romania (automotive, aerospace and IT) in terms of regional development and jobs (See also Ștefan et al., 2016).

Lowell and Gerova (2004) shows that usually expatriates have specialised knowledge and are more prone to invest in their homeland. Also, the lack of capital and the low managerial expertise in the home country limits the effectiveness of investments. The authors mention that there is a substantial amount of evidence of entrepreneurship and investment by the highly skilled, especially in Silicon Valley. According Lowell and Gerova (2004), half of the foreign-born entrepreneurs in Silicon Valley have business relations in their countries of origin.

Diaspora communities could have an essential contribution to the development of Romania, studies showing that Diaspora improve productivity and build physical capital. Also, it boosts job creation, living standards, and economic growth.

According to Foreign Investors Council (2018), with important reforms in education, healthcare and transport infrastructure in the next five years, the return of the 200,000 Romanians (5\%) could (gradually) contribute between 2023 and 2036 with more than 11.5 billion euro to Romania's GDP (Figure 3). This forecast is based on an average productivity of work equal to that existing in Romania.

Having in mind that the Romanian migrant have better skills and human capital, the impact (i.e. value added) should be more important. For example, according to FIC, if the average labour productivity of Romanian migrant would be higher by $20 \%$ comparatively with a domestic worker from Romania, contribution could increase to 14 billion euro in the same period. Also, in a third scenario FIC estimates that cumulated contribution between 2023 and 2036 would be over 17 billion euro if the labour productivity is higher by $50 \%$.

Figure 3. Reverse Migration Projection of Potential Gains for Romania

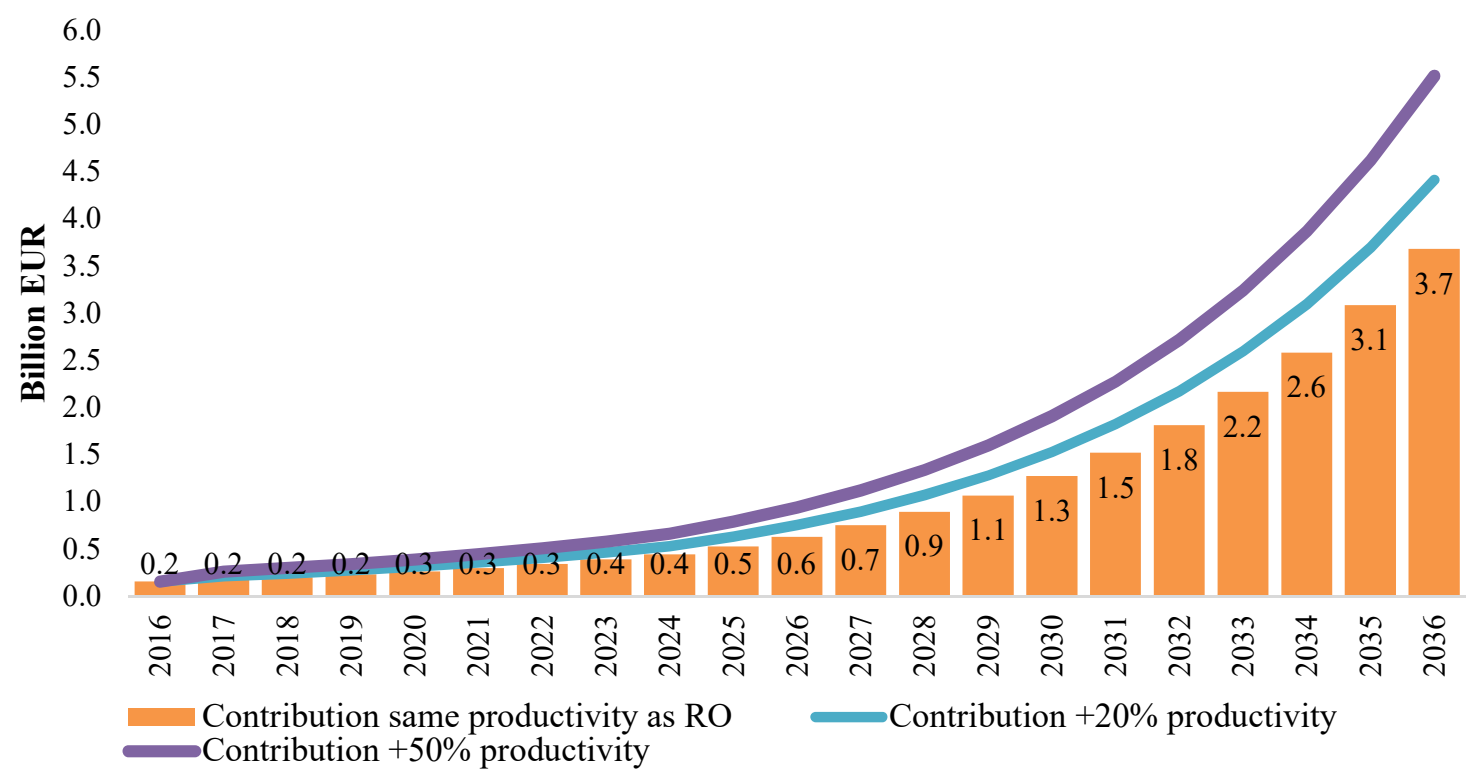

Source: Foreign Investors Council (2018) 


\section{Methodology}

The puzzle that this article is attempting to address is whether or not there is a higher inclination towards entrepreneurship in the case of young people living abroad, and young people living in their home country. In order to keep the object of our enquiry comparable, we explored entrepreneurial intentions with regards to a single targeted country/market: Romania. We thus, compared entrepreneurial intentions of young people from the Romanian Diaspora with those living at home. As such, the present article answers the following research question: To what extend do young Romanians living at home and from the Diaspora have a different entrepreneurial perception/calculus with regards to their home country?

We have deployed over the course of 2016-2017 a survey amongst the Young Romanian Diaspora (i.e. students and young professionals living abroad). We have used the online survey platform Survey Monkey to collect responses from this category of people. We have distributed the survey invitation via the mailing system provided by the platform to approximately 10,000 persons in existent student or professional organisations and to an unknown number of persons via social media groups. We also employed a snow-balling technique to assemble the full set of targeted respondents. The respondents' sample comprises 1,851 persons, which represents a rate of response of approximately $20 \%$.

The geographical distribution of our sample was relatively balanced, with 10 to 50 respondents coming from the following countries: France, Germany, United States of America, Denmark, Italy, Netherlands, Austria, Belgium, Spain and Switzerland. Over 100 respondents come from the United Kingdom. Fewer than 10 respondents came from the following countries: United Arab Emirates, Canada, Sweden, Ireland, Norway, Poland, Turkey, Czech Republic, Cyprus, South Korea, Israel, Japan, Portugal, Thailand, Hungary, Afghanistan, Australia, Brazil, China, Finland, Luxemburg, Malta, Oman, Republic of Moldova, Serbia, Slovakia (see Figure 4).

Figure 4. The Geographical Distribution of Respondents from the Diaspora

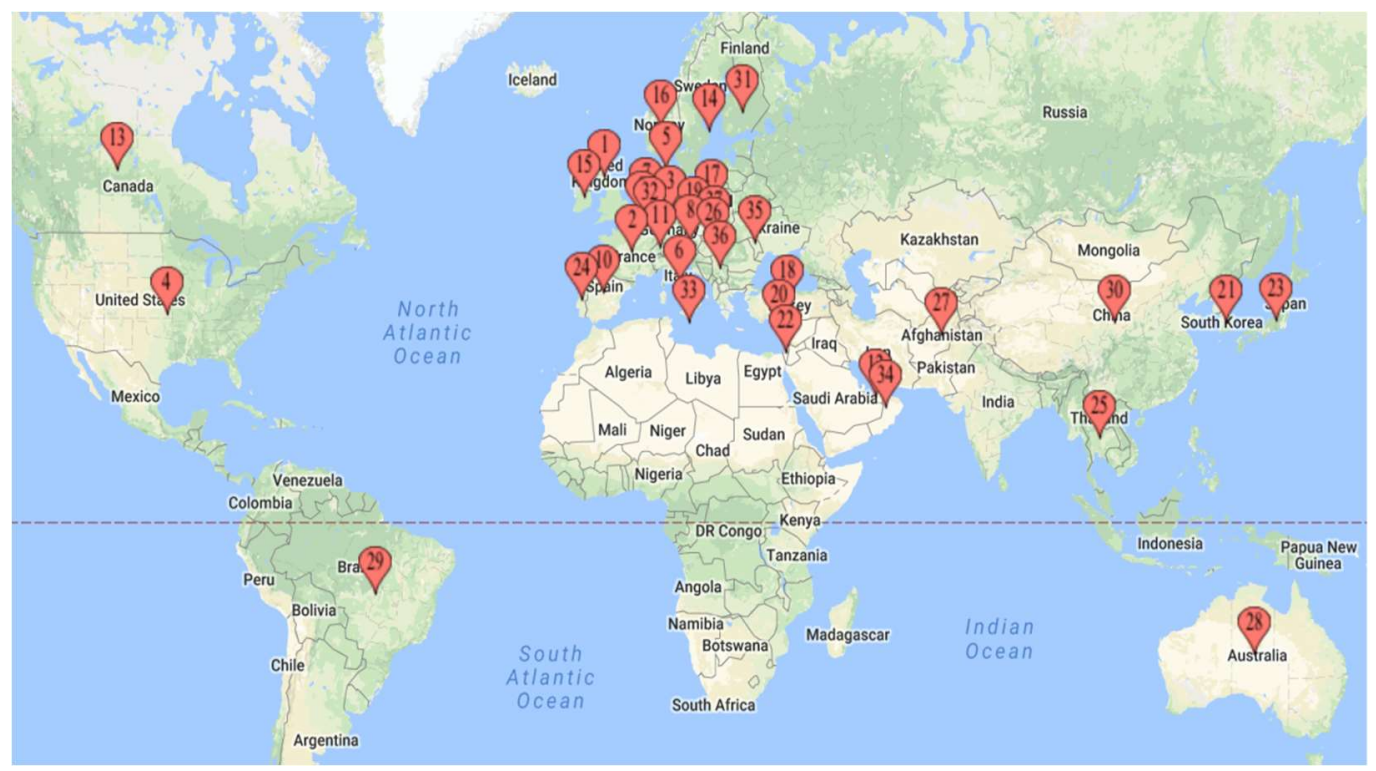

Source: Authors' data 


\section{Figure 5. The Geographical Distribution of Respondents Living in Romania}

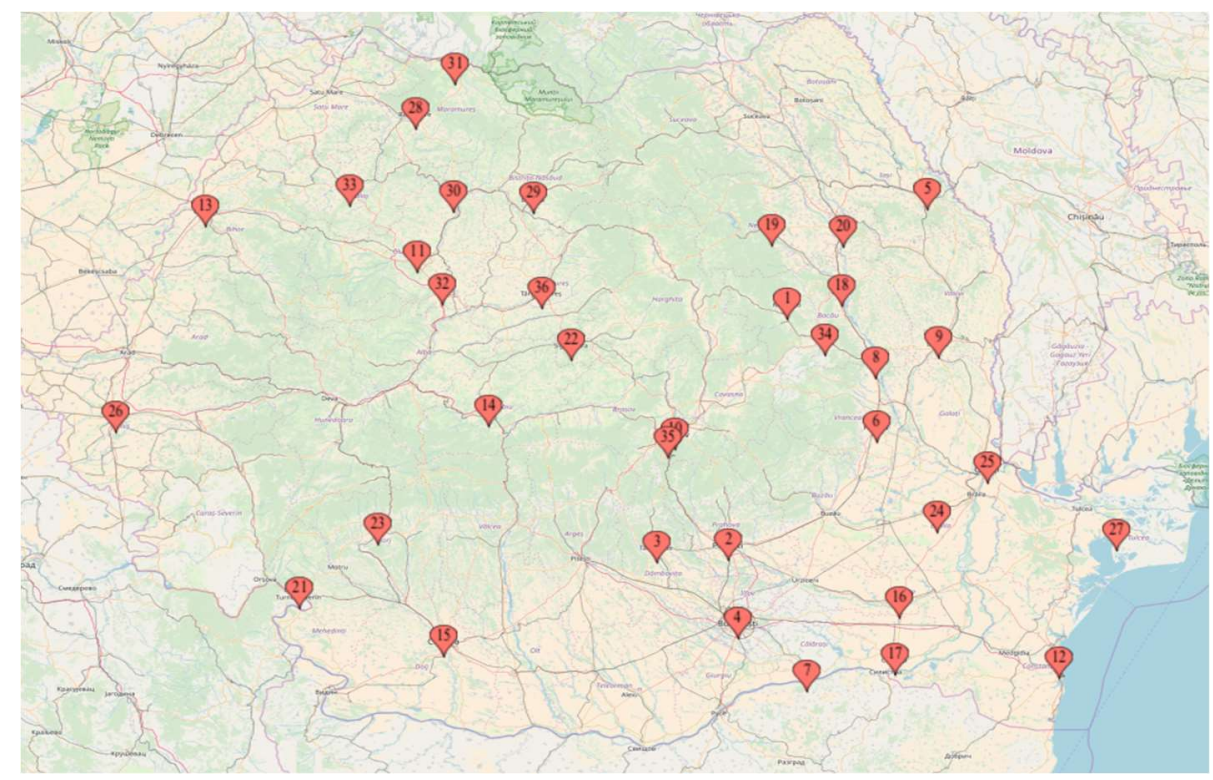

Source: Authors' data

We also use here the data from a survey that was deployed by one of the authors in collaboration with Google Romania, over the course of 2017. It also targeted the same age category as our Diaspora survey: young Romanians. The sample included 4,906 persons and there were 1,108 completed answers collected, which means there was a $22.3 \%$ respondency rate. This survey was distributed from the same online survey platform Survey Monkey, and the same research account, as was the one for the Diaspora. The geographical distribution of the domestic sample was relatively balanced, with respondents from different parts of Romania, in a total of 35 locations (see Figure 5).

In addition, we conducted a total of 24 open interviews with Romanians living in the Diaspora, across Europe and America. The goal of the interviews was to assess the extent to which the entrepreneurial choices considered by the young Romanians living abroad were linked to a specific programme, or life circumstances. We compared the experience of people that were registered in the Diaspora Start-Up EU funded programme, with that of the people engaged in an opposite experience of the Work and Travel Programme in the USA.

Finally, we complemented the qualitative comparative assessment of entrepreneurial perceptions with a quantitative analysis. On one hand, we used the Eurobarometer data to comparatively assess connecting elements of entrepreneurship across EU member states, such as education, ideas, risk-aversion and self-determination. On the other hand, we used statistical data to project different scenarios for long-term impact of reverse migration to Romania. 


\section{Main Findings from Home Country and Diaspora}

According to existing assessments of the economic role the diaspora can play in and for the home country, strings of the literature point to entrepreneurship. With this consideration, we tested various aspects in the case study of the Romanian Diaspora: (1) are young people living abroad inclined to start an entrepreneurial project back home? (2) to what extent do entrepreneurial perceptions (i.e. willingness to open a business in Romania, main challenges, profitable sectors of activity) of Romanians living abroad differ from those living in their home? (3) are the entrepreneurial intentions of the Diaspora anchored in the socio-economic context in their home country or personal traits and considerations? (4) if they were to return (for entrepreneurial projects or otherwise), what is the potential economic impact of the Romanian Diaspora?

In both the home country and in the Diaspora, young Romanians seem equally more inclined to start a business venture in the near future in Romania. There is a clear majority in our two sample groups that would like to have a start-up. Nevertheless, while $84 \%$ of those living in Romania would start their own business, relatively fewer-79\% of those living in the Diaspora, would start their own business in Romania (Figure 6). Overall the figures are remarkably similar in terms of inclination to start ones' own business in Romania, given that for the sample group from the Diaspora there are potentially more challenges in terms of relocation and familiarisation with context.

We explored the age category of young professionals with the specific intention to keep the latter factors at a minimal potential impact on one's decision to start a business back home. Arguably young professionals have either fewer attachment elements in the countries in which they reside and/or have not been away for too long (many of them having left to do their university studies abroad) which means they would not be too disconnected from the business realities and broader socio-economic context in Romania.

Figure 6. Young Romanians' Willingness to Launch a Start-up in Romania?

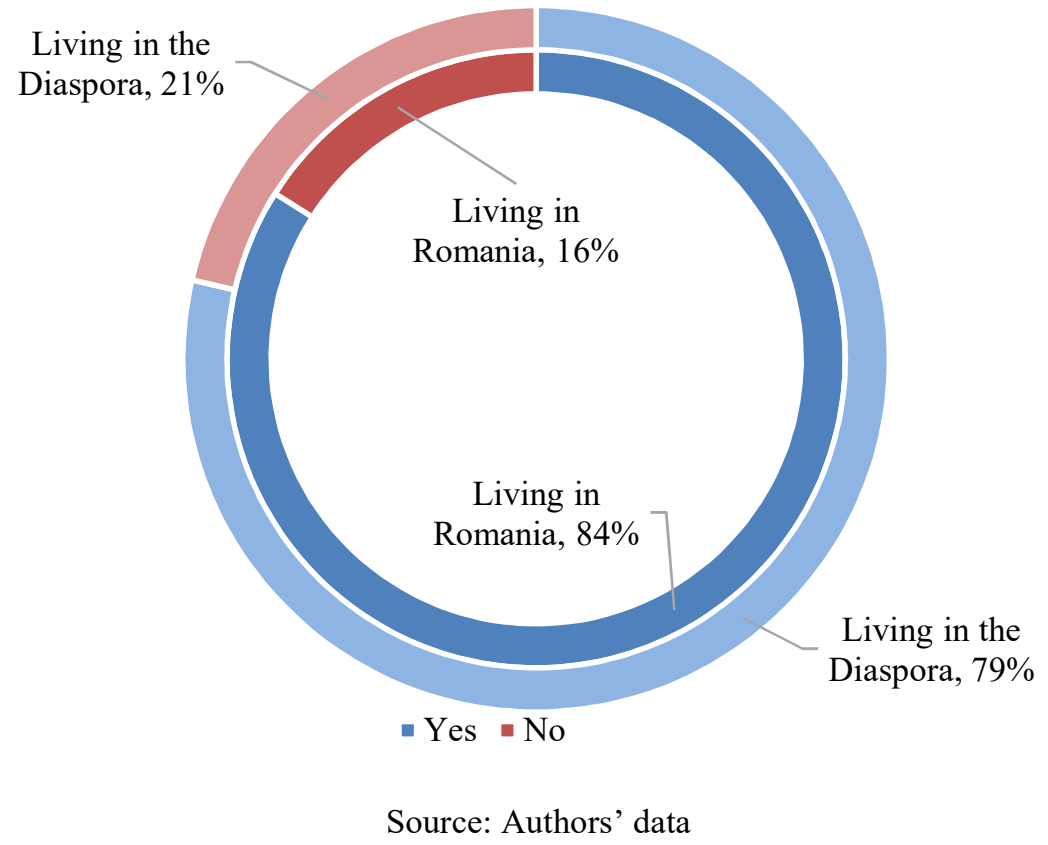


We can see in Figure 7 that the first option young Romanians as a domain in which to open a start-up is IT\&C: $38.21 \%$ of Romanians living in their home country and $35.67 \%$ of Romanians living abroad. Furthermore, the preferences differ to a large extent between Romanians from the Diaspora and those living in Romania.

For the Diaspora amongst the top fields of interest for entrepreneurial activity are: Accommodation and Food Service Activities (22.15\%), and Arts, Entertainment and Recreation (18.57\%). In contrast, for young Romanians who live in their home country, the top fields of attraction in launching an entrepreneurial project are: Construction $(30.56 \%)$ and Electricity, Gas, Steam and Air Conditioning Supply (20.27\%). In this sense, we can see that beyond the top preference for the IT\&C sector, there is not much overlap of preferences between Romanians in the Diaspora and those that reside in Romania (see Figure 7). This would suggest that the perceptions of potentially lucrative fields of activity are significantly different based on proximity with the targeted market.

Figure 7. Young Romanians' Fields of Interest for Entrepreneurial Activities (\%)

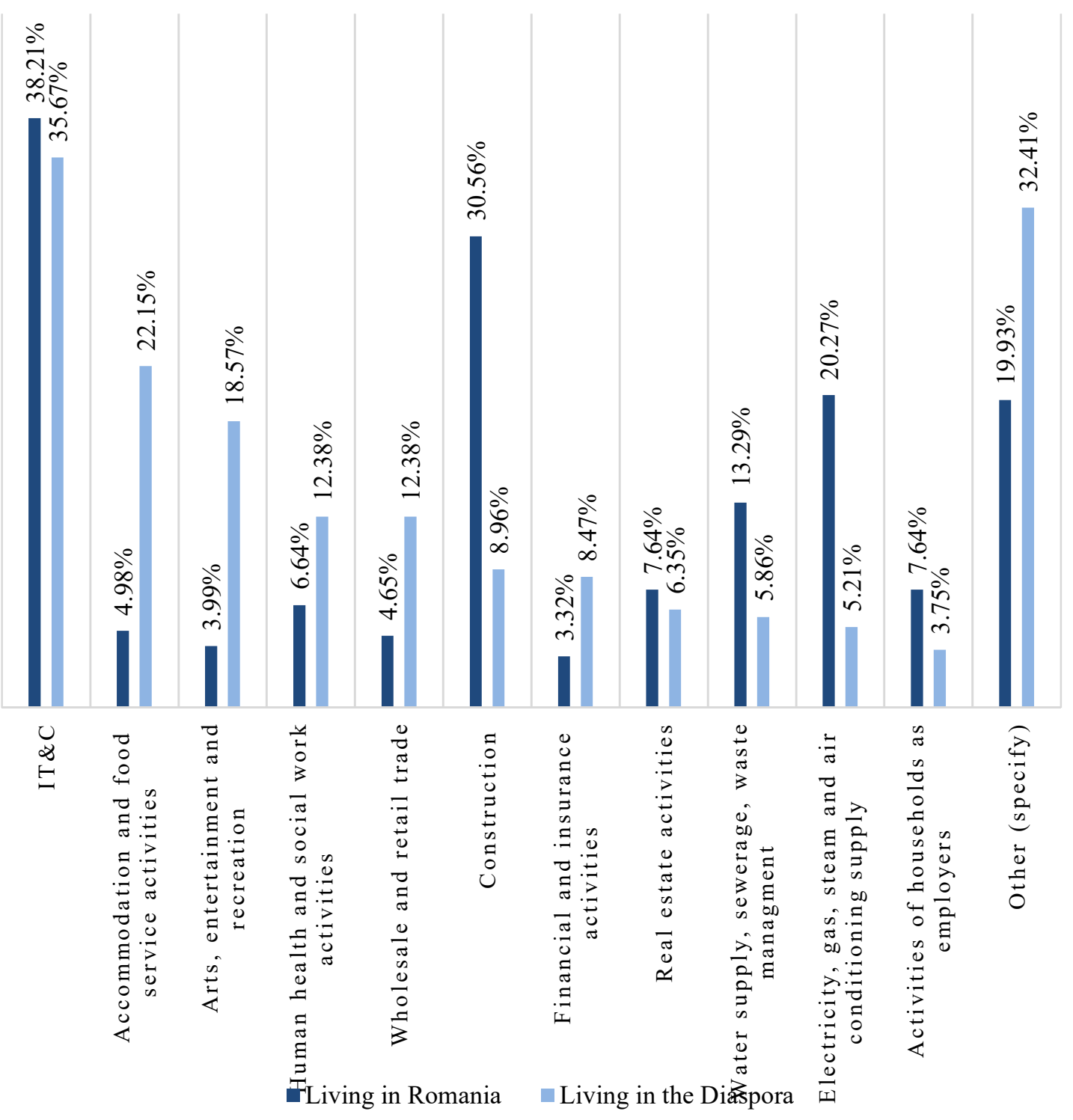

Source: Authors' data 
Figure 8. Main Challenges Perceived by the Young Romanians (\%)

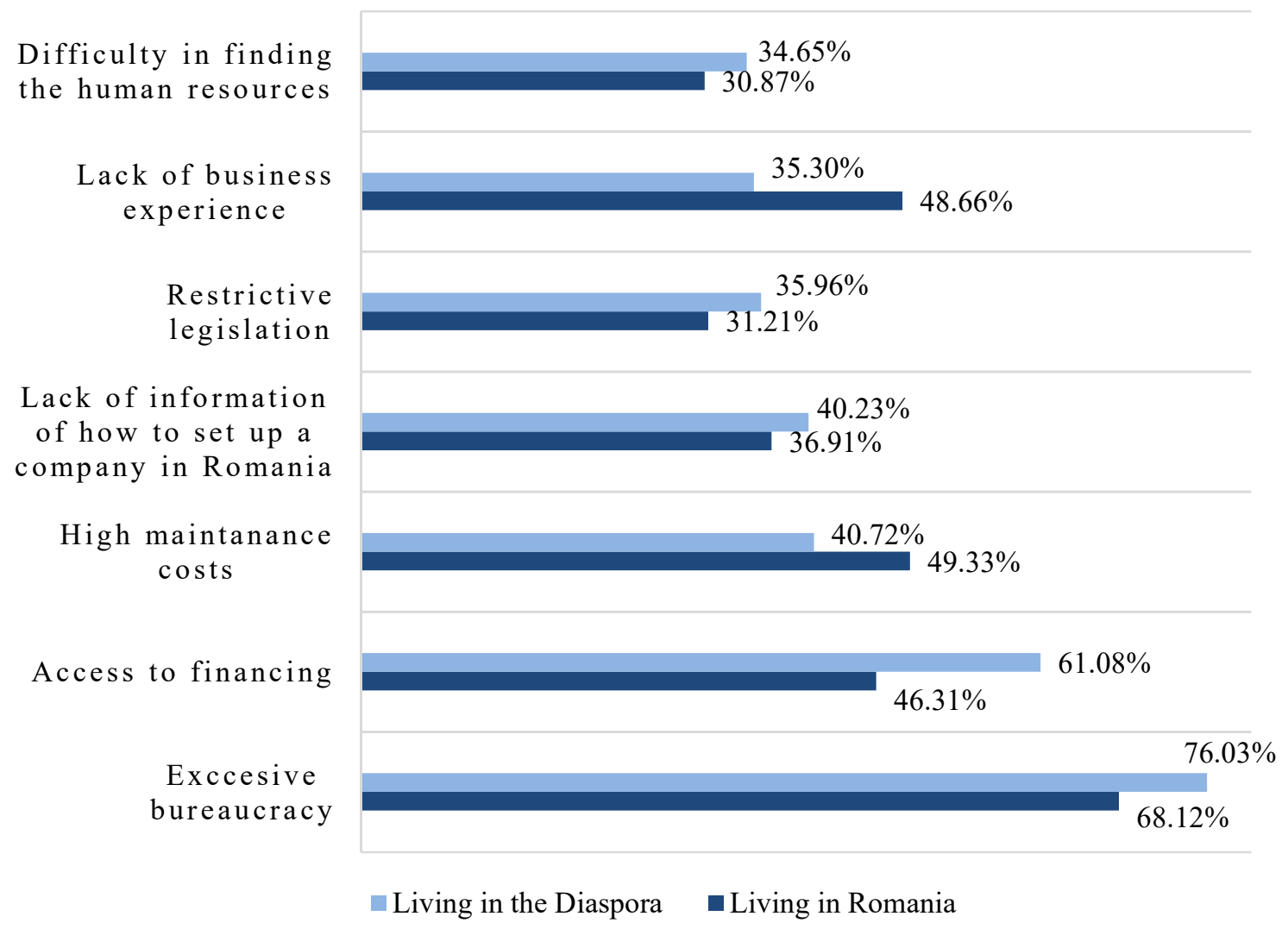

Source: Authors' data

In terms of the main barriers to opening a business, as they are perceived by the respondents, we once again see a high convergence with regards to their top concern, but a relative divergence with regards to the weight of other concerns for the two categories of subjects. Both for young Romanians from the Diaspora and young Romanians living at home, the biggest concern in starting an entrepreneurial project is excessive bureaucracy. The concern with regards to bureaucratic impediments is slightly higher for Romanians living abroad (76.03\%) in comparison to those residing in their home country $(68.12 \%)$. Further on, for the Romanians living in their home country, the next most important concerns were: the high maintenance costs $(40.72 \%)$, and lack of business experience (48.66\%). In slight contrast, for the Romanians living in the Diaspora, having access to financing $(61.08 \%)$, and the lack of information on how to set up a company in Romania $(40.23 \%)$. We can once again see that context can be suspected to play a role in the attitudes towards starting an entrepreneurial project.

In what concerns the Romanians in the Diaspora, we can plausibly assess distance to inform the weighted ranking the respondents gave to the main challenges they face in opening a business of their own. Our study is informative to the academic public and public sector alike, as it proves that there is an information asymmetry between young entrepreneurs living in their home country and those in the Diaspora with regards to the Romanian market. Romanians living abroad do not seem to have or perceive to have the same level of information and expertise as those living at home. Bearing in mind that these are perceptions and not actual knowledge tests, the information or experience asymmetry may 
be either based in intrinsic individual knowledge or in relatively different contextual circumstances (i.e. people from the Diaspora expect they should have more business experience than those living at home).

In terms of previous experience, there is again a relative difference between the two samples analysed here, as the majority of respondents from the Diaspora are currently employed in a private company $(42.60 \%)$, while the majority of the respondents from Romania are currently students (47.21\%) (see Figure 9). There is a slight skewedness in the average age of the two samples - 23.3 years for the domestic sample, and 25.7 years for the diaspora. While it is arguable that there is an important threshold in the transition from undergraduate studies to employment exactly in between 23 and 25 years, the samples themselves have a relatively proportional distribution, thus the age effect cannot explain by itself the degree of difference in the distribution of current status. Rather, as in the previous data interpretation presented here, we ascribe differences in respondents' traits to contextual differences from the environment in which they reside. We do not have enough data on the diaspora to assess differences in this subcategory from country to country. But in general, we can see a pattern of differentiation between the predominant status of students of the young Romanians living in their home country, and the predominant status of being employed in a private company of young Romanians living abroad.

Figure 9. Current Labour Market Status of the Respondents (\%)

Employee in a private company

Student
Open to labour market
opportunities

Employee in a public institution

I run my own company

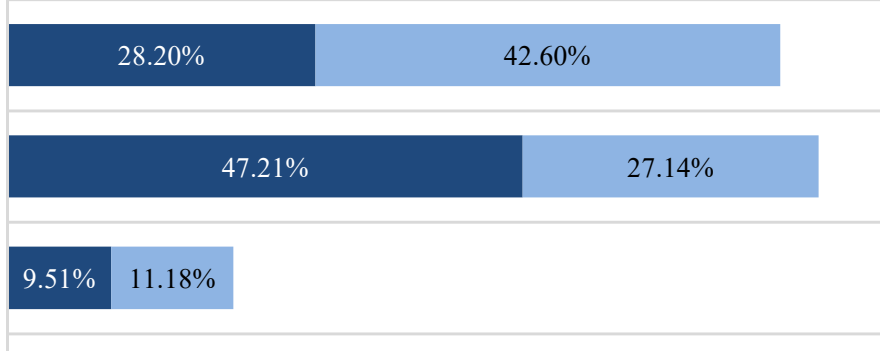

$10.16 \% \quad 10.03 \%$

\section{- Living in Romania Living in the Diaspora}

Source: Authors' data

The interview data concurs with the findings of the surveys, in the sense that it seems to be a much higher influence of personal circumstances that informs the consideration of starting an entrepreneurial project than objective calculations of contextual circumstances in the home country. We conducted interviews with young Romanians facing different incentives. The first category comprised of young Romanians in the Diaspora the were registered in the Diaspora Start-Up project that is a competition of business plans for a startup grant of approximately 40,000 EUR. The second category comprised on young Romanian students enrolled in the Work and Travel Programme that would create the opportunity of working over the summer in USA. We considered the two programmes to be differentiating experiences in relation to the home country, as one is offering pull factors 
(i.e. Diaspora Start-Up), while the other is offering push factors (i.e. Work and Travel). In both categories of respondents, we found very similar rationales of coming back home with the purpose of starting one's business, as opposed to the idea of finding employment in Romania. In the majority of interviews, it was not a funding programme or the context in the home country that was triggering the decision to move back to start an entrepreneurial project, but the private circumstance in the person's life.

\section{Concluding Remarks}

Firstly, Romanian diaspora seems to be open to entrepreneurial projects in their home country. Approximately $80 \%$ of young Romanians living in the diaspora are willing to start a business in their home country. Given the sample we used comprised of students and young professionals we cannot expand our results to the entire population of the Romanian diaspora, but we do expect the targeted group in our survey to be highly relevant for the topic of the enquiry with a high potential to succeed in the entrepreneurial projects they might undertake.

Secondly, the comparison between the perceptions and preferences of young Romanians living abroad and those from the home country do not differ significantly: the vast majority in both cases would launch a start-up in Romania, and in both cases the most likely field of activity would be IT\&C, while excessive bureaucracy is the main impediment perceived by both categories of respondents. Using interviews data, and the subsequent assessment of the Eurobarometer relevant data (in the following subsection) we can infer that it is mostly personal traits and preferences that inform the option of starting an entrepreneurial project in Romania, and not an in-depth assessment of the socio-economic conditions of their home country.

Finally, we attempted to point to potential gains that the manifested intentions of the diaspora respondents could yield if they turn into real projects. As the following subsection shows, the return of the 200,000 Romanians (5\%) could (gradually) contribute between 2023 and 2036 with more than 11.5 billion euro to Romania's GDP.

\section{Acknowledgements:}

Without the unwaivering support of Professor Rodica Zaharia, this article would not have been possible. We are very grateful for the access to data and support provided by Alina Arsăni, Raluca Popa, Dragoș Preda, Sebastian Burduja, and David Timiș. Our gratitude for support in the distribution of this questionnaire goes to representatives of the C.A.E.S.A.R. (Centre for Accessing the Expertise of Romanian Students and Professionals) Foundation and LSRS (League for Romanian Students Abroad).

\section{References:}

Beine, M., Docquier, F., Rapoport, H. (2001). Brain drain and economic growth: theory and evidence. Journal of development economics, 64(1), 275-289.

Castles, S., De Haas, H., \& Miller, M. J. (2013). The age of migration: International population movements in the modern world. Macmillan International Higher Education.

Castells, M. (2011). The rise of the network society. John Wiley \& Sons. 
Chaliand, G., Rageau, J.P. (1995). Atlas historique du monde méditerranéen: chrétiens, juifs et musulmans de l'Antiquité à nos jours. Payot.

CityLab (2017). https://www.citylab.com/life/2017/09/european-demographics-agingemployment-migration/540084/

Cohen, R. (2008). Global diasporas: An introduction. Routledge.

Cristea, M. et al (2017). Magnet Cities: Migration and Commuting in Romania. World Bank Report.

European Commission, Flash Eurobarometer 283: Entrepreneurship in the EU and beyond - A survey in the EU, EFTA countries, Croatia, Turkey, the US, Japan, South Korea and China https://data.europa.eu/euodp/data/dataset/S765_283

Eurostat (2018). Newsrelease 87/2018 - 28 May 2018, https://ec.europa.eu/eurostat/documents/2995521/8926076/3-28052018-AP-EN.pdf/48c473e8c2c1-4942-b2a4-5761edacda37

Foreign Investors Council (2018). Romania, a zecea economie din UE în anul 2036. May 2018. https://vaurma.ro/wp-content/uploads/2018/06/VA-URMA.pdf

Giddens, A. (2013). The consequences of modernity. John Wiley \& Sons.

Giddens, A. (2018). Globalization. In Sociology of Globalization (pp. 19-26). Routledge.

Gribble, C. (2008). Policy options for managing international student migration: the sending country's perspective. Journal of Higher Education Policy and Management, 30(1), 25-39.

Hirst, P., Thompson, G., \& Bromley, S. (2015). Globalization in question. John Wiley \& Sons. Held, D., McGrew, A. G. (Eds.). (2007). Globalization theory: Approaches and controversies. Cambridge: Polity.

Kalra, V., Kaur, R., Hutnyk, J. (2005). Diaspora and hybridity. Sage.

Lowell, B.L., Gerova, S.G. (2004). Diasporas and economic development: State of knowledge. Washington: Institute for the Study of International Migration, Georgetown University.

Newland, K., Tanaka, H. (2010). Mobilizing diaspora entrepreneurship for development. Washington, DC: Migration Policy Institute.

O'Sullivan, F. (2017). Mapping Where Europe's Population Is Moving, Aging, and Finding Work. Papastergiadis, N. (2018). The turbulence of migration: Globalization, deterritorialization and hybridity. John Wiley \& Sons.

Riddle, L., Hrivnak, G. A., Nielsen, T. M. (2010). Transnational diaspora entrepreneurship in emerging markets: Bridging institutional divides. Journal of International Management, 16(4), 398-411.

Ștefan, G., Popa, R.A., Arsăni, A. (2016). The Evolution of State Aid in Romania. Analysis of the Automotive Sector 2007-2015, Scientific Bulletin - Economic Sciences, 2016, vol. 15, issue 2, 77-92

United Nations (2018). Romania. https://esa.un.org/miggmgprofiles/indicators/files/Romania.pdf

Van Hear, N. (2005). New diasporas. Routledge.

World Bank (2018). Migration and Remittances Data.

http://www.worldbank.org/en/topic/migrationremittancesdiasporaissues/brief/migrationremittances-data

Zaharia, R., Ban, C., Popescu, A. (2016). Relația dintre fenomenul migrației legale și piața muncii din România. Evoluții relevante, impact potențial, recomandări de politici publice. Studii de Strategie și Politici Publice 2016, Institutul European din România, http://www.ier.ro/sites/default/files/pdf/SPOS_2016_\%20Migratia_legala_si_piata_muncii.pdf 